\title{
The Middle Ordovician conodonts Eoplacognathus robustus Bergström and E. lindstroemi (Hamar): Taxonomy and apparatus reconstruction
}

\author{
*Susana Heredia', Ana Mestre ${ }^{1}$ \\ ${ }^{1}$ CONICET-Instituto de Investigaciones Mineras (UNSJ). Libertador 1109, San Juan (5400), Argentina. \\ sheredia@unsj.edu.ar; amestre@unsj.edu.ar \\ *Corresponding author: sheredia@unsj.edu.ar
}

\begin{abstract}
The Middle-Upper Ordovician Ponón Trehué Formation cropping out in the San Rafael Block (Argentina) provided a large collection of conodonts which have been published years ago. The species Eoplacognathus robustus and Eoplacognathus lindstroemi recovered from these strata have been revised and restudied. In this contribution we describe $\mathrm{M}$ and S elements that were assigned previously to Baltoniodus prevariabilis and Baltoniodus variabilis as belonging to the E. robustus and E. lindstroemi apparatuses. The morphological characters of the $\mathrm{P}, \mathrm{S}$ and $\mathrm{M}$ elements as part of these late Eoplacognathus apparatus were analyzed and support the proposal of a new reconstruction of it. We have compared this apparatus with the Baltoniodus apparatus and suggest the inclusion of the Eoplacognathus genus into the Balognathidae family. The new architecture of the Eoplacognathus apparatus is comparable to the genus Lenodus. This analysis improves the knowledge about this index conodont group allowing a new insight on the evolution, phylogeny and paleobiology of this linage.
\end{abstract}

Keywords: Cuyania, Ordovician, Eoplacognathus, Taxonomy.

RESUMEN: Los Conodontes Eoplacognathus robustus Bergström y E. lindstroemi (Hamar) del Ordovícico Medio: taxonomía y reconstrucción de sus aparatos. La Formación Ponón Trehué del Ordovícico Medio-Superior que aflora en el Bloque de San Rafael (Argentina) ha provisto una gran colección de conodontes que se han dado a conocer a través de los años. Las especies Eoplacognathus robustus y Eoplacognathus lindstroemi recuperadas de estos estratos han sido revisadas y reestudiadas. En esta contribución describimos los elementos M y S que se asignaron previamente a Baltoniodus prevariabilis y Baltoniodus variabilis como pertenecientes a los aparatos E. robustus y E. lindstroemi. Se analizaron los caracteres morfológicos de los elementos P, S y M de estos Eoplacognathus tardíos que apoyan la propuesta de una nueva reconstrucción de sus aparatos. Se lo ha comparado con el aparato Baltoniodus y sugerimos la inclusión del género Eoplacognathus en la familia Balognathidae. La nueva arquitectura del aparato de Eoplacognathus es equiparable con la del género Lenodus. Este análisis mejora el conocimiento sobre este grupo de conodontes guía permitiendo una nueva visión sobre la evolución, filogenia y paleobiología de este linaje. 


\section{Introduction}

The Eoplacognathus apparatus was first described and their species defined as zonal and subzonal index conodonts by Bergström (1971), supporting this proposal on the $\mathrm{P}$ elements. This original description is only based on the oral shape of these P elements. The key conodonts E. robustus Bergström and E. lindstroemi (Hamar) document the homonymous subzones for the conodont-bearing strata.

The Middle-Upper Ordovician strata of Ponón Trehué outcrops, exposed in the San Rafael Block (Fig. 1), provided a large collection of conodonts. Previous contributions on this conodont fauna were carried out by Heredia (1982, 1998, 2001, 2002) and Lehnert et al. (1999). Recently Heredia et al. (2014) and Heredia and Mestre (2015) restudy the conodont collection from the Ponón Trehué Formation presenting a new interpretation of the conodont apparatus of Eoplacognathus. A deeper revision of these materials allow us to assign $\mathrm{S}$ and M elements previously assigned to the Baltoniodus species as belonging to the E. robustus and $E$. lindstroemi apparatuses.
The main purpose of this contribution is to analyze the morphological characters and taxonomy of P elements of Eoplacongathus robustus and E. lindstroemi, and include $\mathrm{S}$ and $\mathrm{M}$ elements as part of the Eoplacognathus apparatus, thereby proposing a new reconstruction of it; additionally, we compare it to the Baltoniodus apparatus.

\section{Geological setting}

Within the Ponón Trehue region is located the only preserved record in all Cuyania of the Lower Paleozoic carbonate-siliciclastic succession in depositional contact with basement rocks. This basement is interpreted to be of Grenvillian (late Mesoproterozoic) age (Ramos, Vujovich and Dallmeyer, 1996; Cingolani and Varela, 1999) and constitutes the Cerro La Ventana Formation.

The outcrops in the Ponón Trehué area allow for the recognition of three different units. One is composed entirely of the Mesoproterozoic basement. The other two are sedimentary units that include varying amounts of reworked basement rocks. A well-established Ordovician clastic succession of

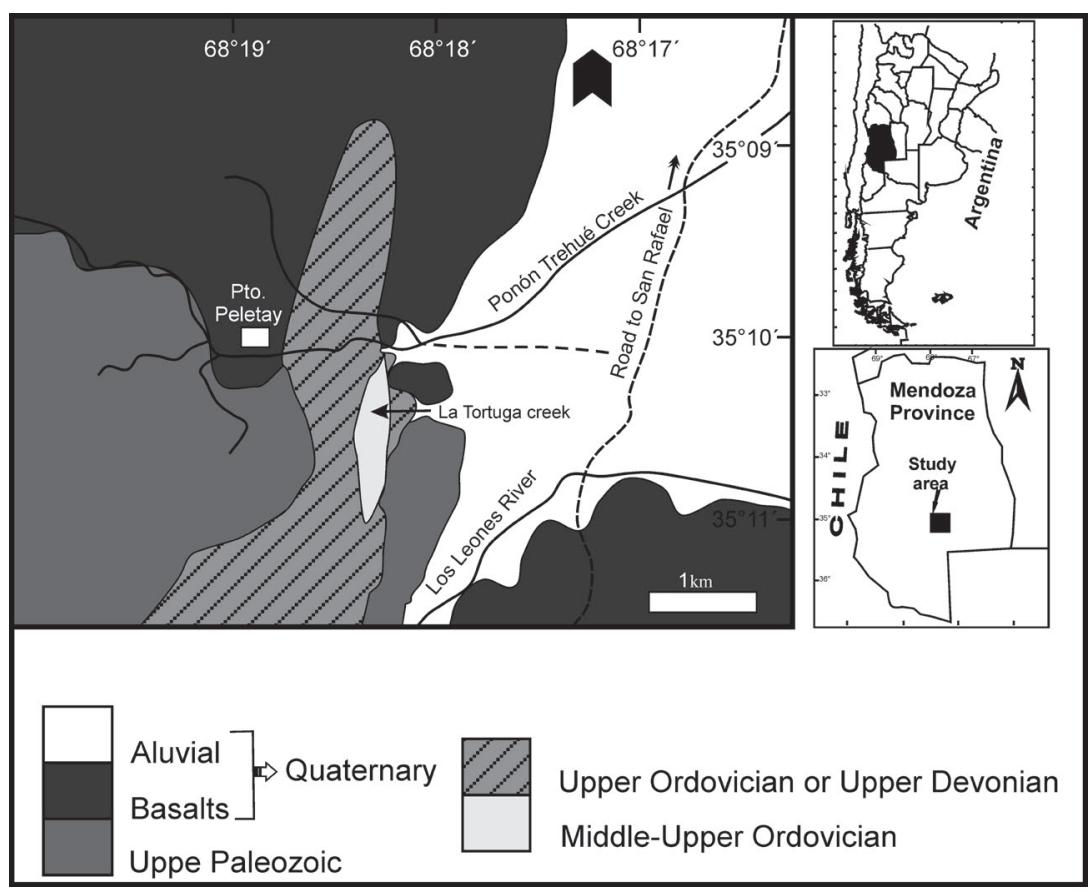

FIG. 1. Location map of the Ponón Trehué region (Mendoza Province) showing studied section, La Tortuga creek (Modified from Heredia and Mestre, 2017). 
the Ponón Trehué Formation (upper Darriwilian to lower Sandbian) is composed of granite conglomerate, sandstone and thin-bedded, fossiliferous limestone. A significant unconformity can be traced between the Ordovician clastic sequence and the underlying basement, exposed to the east. The dominant features of these Mesoproterozoic and Ordovician rocks are their isolate, discontinue and disperse outcrops in a green shale matrix suggesting an olisthostromic origin for these deposits (Heredia and Mestre, 2017). Astini (2002) considered that the limestone outcrops of the Ponón Trehué Formation (sensu Bordonaro, Keller and Lehnert, 1996) were blocks and fragmentary carbonate bodies discontinuously exposed, floating in arkose conglomerate, in agreement with Heredia (1998, 2001), Beresi and Heredia (2000) and Heredia and Mestre (2017). In spite of these interpretations these deposits are informative about their fossil record and history.

The Ordovician outcrops in Ponón Trehué represent a depositional cycle from shallower to deeper environments. This succession involves two different deposits: the lower one comprises coarse siliciclastic deposits and the upper one consists of fine, dark carbonate-fine clastic deposits. The biostratigraphy of these Ordovician outcrops has been based on conodonts, recognizing two biozones: the Pygodus serra Zone and Pygodus anserinus Zone (Heredia, 1982; Bordonaro, Keller and Lehnert, 1996; Heredia, 1996; Lehnert et al., 1999; Heredia, 2001; Cingolani and Heredia, 2001; Heredia and Mestre, 2017) (Fig. 2). Brachiopods, sponge spicules (Beresi and Heredia, 2000), bryozoans, ostracodes, crinoids, trilobites and algae fragments were also recovered from the analyzed samples.

\section{Previous Considerations On Taxonomy}

The family Polyplacognathidae Bergström, 1983 including Polyplacognathus Stauffer, 1935; Eoplacognathus Hamar, 1966; Cahabagnathus Bergström, 1983 (Sweet, 1981). All these genera are characterized exclusively by bimembrate apparatuses with bilaterally asymmetrical stelliplanate $\mathrm{Pa}$ element (polyplacognatiform element) and pastiniplanate $\mathrm{Pb}$ element (Sweet, 1988). Later, Stouge and Bagnoli (1999) included to Polonodus Dzik, 1976; Yangtzeplacognathus Zhang, 1998; and Baltoplacognathus Zhang, 1998, into this family without any reference to the basal cavity morphology.
These are well known from numerous studies of abundant material throughout Middle Ordovician sections in Baltoscandia, North America, Argentina and China.

Bergström (1971) provided the first description of the Eoplacognathus apparatus based only on $\mathrm{P}$ elements of the species Eoplacognathus lindstroemi (Hamar, 1964), namely two ambalodiform $(\mathrm{Pb})$ and one polyplacognathiform $(\mathrm{Pa})$ elements. Lindström (in Ziegler, 1973) presented a reviewed diagnosis recognizing two ambalodiform $(\mathrm{Pb})$ and one amorphognathiform $(\mathrm{Pa})$ elements. This author changed drastically the idea of the genus Eoplacognathus from polyplacognathiform (stelliplanate) to amorphognathiform (pastiniscaphate) elements (Lindström in Ziegler, 1973).

Dzik (1976) considered that the evolution process of the Eoplacognathus species let only platform elements $(\mathrm{Pa}$ and $\mathrm{Pb})$ in the apparatus. Later, Dzik (1994) described a multielemental apparatus for the earliest species of the genus Eoplacognathus: E. zgierzensis Dzik, conformed by $\mathrm{Pa}, \mathrm{Pb}, \mathrm{S}$ and M elements.

Stouge and Bagnoli (1990) reported for the first time $\mathrm{S}$ and $\mathrm{M}$ elements in the apparatus of Eoplacognathus pseudoplanus proposing a change in this genus name to Lenodus pseudoplanus, including the genus Lenodus to the Balognathidae Family. Stouge and Bagnoli (1999) kept the genus Eoplacognathus in the Polyplacognathidae. However, Löfgren and Zhang (2003) continue to use the designation Eoplacognathus pseudoplanus, and they recognized $\mathrm{S}$ and $\mathrm{M}$ elements for this species. Melgren et al. (2012) recognized S elements in the E. foliaceous apparatus.

A detailed review of the P elements basal cavity from the Eoplacognathus species showed that is different in earlier representatives comparing with later ones, been the first ones scaphate (E.pseudoplanus to E. robustus species) and the later ones are planate (E. lindstroemi and E. elongatus species). This character appeared earlier in the E. robustus sinistral Pa element. We propose that this feature can be used as tool for species recognition between E. robustus and E. lindstroemi.

Zhang (1998) studied the Polyplacognathidae family proposing changes in its interpretation, recognizing two new genera Baltoplacognathus and Yangtzeplacognathus, together with EoplacognathusPolyplacognathus and Cahabagnathus represent 


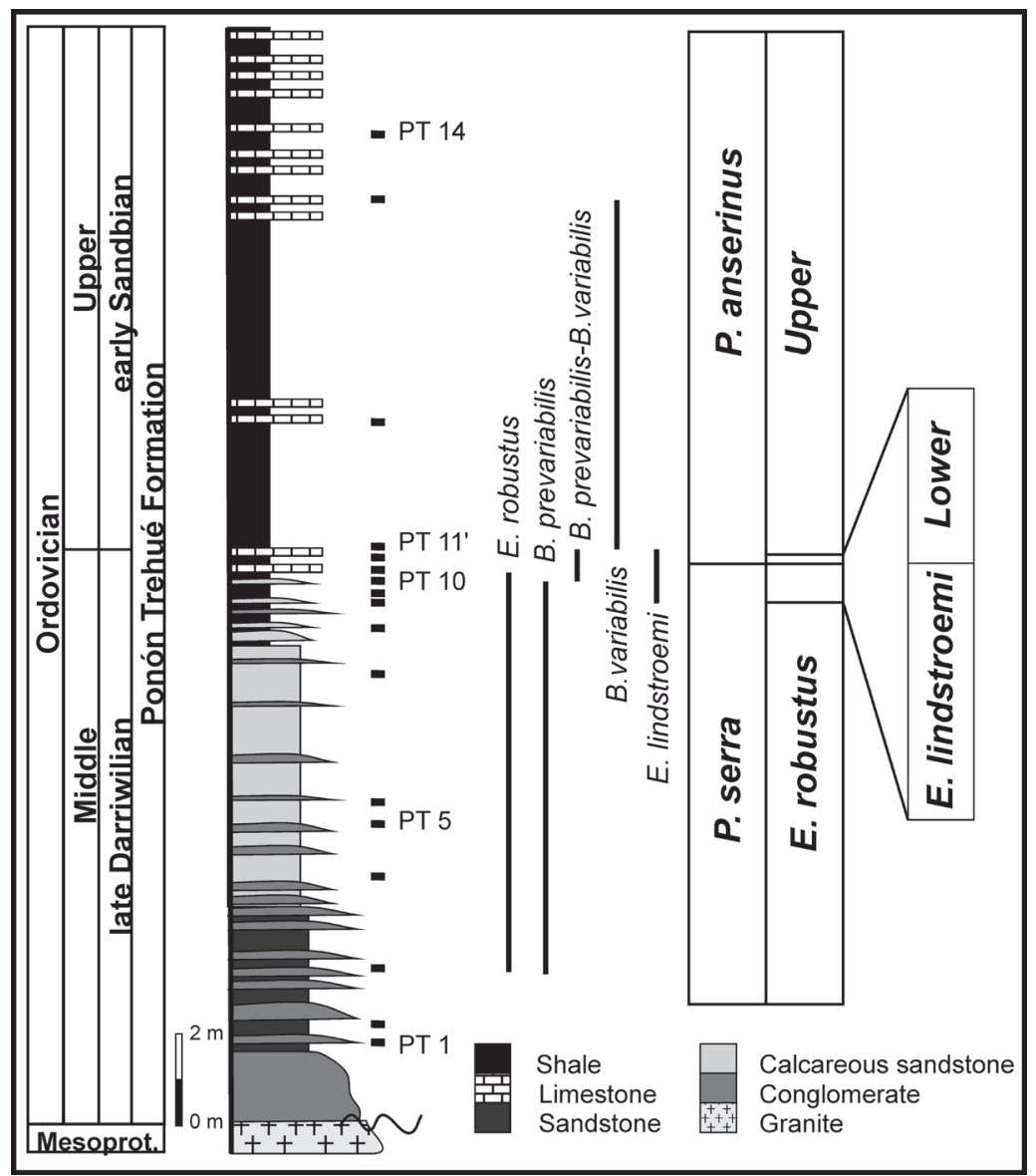

FIG. 2. Stratigraphic column in La Tortuga section with the ranges of the selected conodont species and conodont biostratigraphical scheme for the Ponón Trehué Formation (Modified from Heredia and Mestre, 2017).

four evolutionary lineages in the Middle Ordovician. The index species Yangtzeplacognathus foliaceous, Baltoplacognathus reclinatus, B. robustus, E. lindstroemi and E. elongatus were redefined among others. Zhang (1998) supported this proposal based on differences on the morphological features of the $\mathrm{Pa}$ elements (Baltoplacognathus) or $\mathrm{Pb}$ elements (Yangtzeplacognathus), linking them discontinuously. Especially the differences between both genera are expressed mainly in the length and width of the processes and angles between them, whereas the differences between species of the first genus lie on the denticles row of the processes (Zhang, 1998).

Several elements identified as E. robustus$E$. lindstroemi transitional forms were recovered from the PT10 sample, in the Ponón Trehué section (Heredia, 2002). These types of elements are defined as a transitional form due to the features that exhibit such as size and shape of the processes and lobes. There is a trend that can be followed in the $\mathrm{Pa}$ element morphology of the species E. robustusE. robustus/E. lindstroemi transition- E. lindstroemi. Based on this evidence, we reject the use of the genus Baltoplacognathus for the species robustus.

The basal cavity of the Eoplacognathus P elements was shortly described by Bergström (1971). He mentioned that the basal cavity is scaphate in juvenile specimens and planate in mature specimens for the most of species of this genus, except $E$. lindstroemi and E. elongatus. These descriptions do not reflect the true morphology of the basal cavity, after that we consider the necessity of taxonomical revision of this genus. Descriptions of the P element basal cavities are herein developed, it is worth noting that they are different in the early E. robustus species when compared to the descendent $E$. lindstroemi, being the 
first one scaphate and the later one are planate. We propose that this feature could be used as an additional tool for diagnosing between $E$. robustus and $E$. lindstroemi.

\section{Taxonomy}

The synonymy lists are condensed, mostly containing only the original citations of species names incorporated in each multielement taxon. In the descriptions, we have used the conventional orientational terms -anterior, posterior, and lateralnoting these do not relate to the anatomical orientation of elements (see Purnell et al., 2000).

The S elements location in the Baltoniodus apparatus follows the Stouge and Bagnoli (1999) interpretation of it.

Order Prioniodontida Dzik, 1976

Superfamily Prioniodontacea Bassler, 1925

Family Balognathidae Hass, 1959

Genus Eoplacognathus Hamar, 1966

Type species. Ambalodus lindstroemi Hamar, 1964

Eoplacognathus robustus Bergström Fig. 3, A-J

1971. Eoplacognathus robustus n. sp. Bergström, p. 140, Pl. 1, 14-16.

1976. Eoplacognathus lindstroemi robustus Bergström, Dzik: Text-fig. 32 A-C.

1985. Eoplacognathus robustus Bergström, Bergström and Orchard: PI. 2.2, 8, 12.

1994. Eoplacognathus robustus Bergström, Dzik: p. 98, PI. 21, figs. 3-5, text. 23.

1998. Eoplacognathus robustus Bergström, Heredia: p. 341, PI. I, fig. 3-11, text-fig. 3.

1998. Baltoplacognathus robustus (Bergström), Zhang: text.fig. 7, H-N.

1999. Baltoplacognathus robustus (Bergström), Stouge and Bagnoli: Pl. 2, fig. 9-12.

2001. Eoplacognathus robustus Bergström, Heredia: Pl.1, fig. 3

2011. Baltoplacognathus robustus (Bergström), Viira: fig. 9, F.

2012. Baltoplacognathus robustus (Bergström), Hints, Viira and Nõlvak: fig. 5, D-F.

2016. Baltoplacognathus robustus (Bergström), Wu et al.: fig. $3,6$.

2016. Baltoplacognathus robustus (Bergström), Stouge et al.: fig. 3, H-I.
Materials. Fifty four elements. Seventeen Pa, eighteen $\mathrm{Pb}$, six $\mathrm{S}$, and three $\mathrm{M}$ elements.

Description. The dextral and sinistral $\mathrm{Pa}$ and $\mathrm{Pb}$ elements are pastinicaphate with wide basal cavity that occupies all the aboral side (Fig. 3 E). These elements agree well with Bergström's (1971) oral description.

M. The M element is represented by a modified geniculate morphology. The cusp is erect and has a central carina on the inner side, and is longer than the anterior margin. The angle between anterior margin of the cusp and the anterior margin of the base is greater than $180^{\circ}$. The angle between anterior and oral margins is less than $90^{\circ}$ and has a U-like shape.

Sa. The Sa element has an alate morphology. The element has three regularly denticulate processes. The denticles are fused in the base and climb through the cusp.

Sb. The tertiopedate element, clearly asymmetrical. The cusp is short, erect to the tip. The three processes have regular proclined denticles toward the cusp.

Sd. The symmetrical quadriramate elements has a short cusp and all processes are regularly denticulate and they are connecting with the cusp through a carina.

Eoplacognathus lindstroemi (Hamar, 1964)

Fig. 4, A-G

1964. Ambalodus lindstroemi n. sp. Hamar, p. 258, PI. 5, 1, 4, 7-8, 10-11, text-fig. 5, 1, 3-4.

1971. Eoplacognathus lindstroemi (Hamar), Bergström: p. 139, Pl. 2, 15-18.

1985. Eoplacognathus lindstroemi (Hamar), Bergström and Orchard: PI 2.2, 11, 13.

1994. Eoplacognathus lindstroemi (Hamar), Dzik: p. 98, PI. 21, 6-9, text-fig. 23.

1998. Eoplacognathus lindstroemi (Hamar), Zhang: text.fig. 8, A-K.

1999. Eoplacognathus lindstroemi (Hamar), Stouge and Bagnoli: PI. 2, fig. 5-8.

2001. Eoplacognathus lindstroemi (Hamar), Heredia: PI. 3, 6, 13.

2011. Eoplacognathus lindstroemi (Hamar), Viira: fig. 9, G.

2012. Eoplacognathus lindstroemi (Hamar), Hints, Viira and Nõlvak: fig. 5, G-I.

2016. Eoplacognathus lindstroemi (Hamar), Stouge et al.: fig. 3, N-P. 


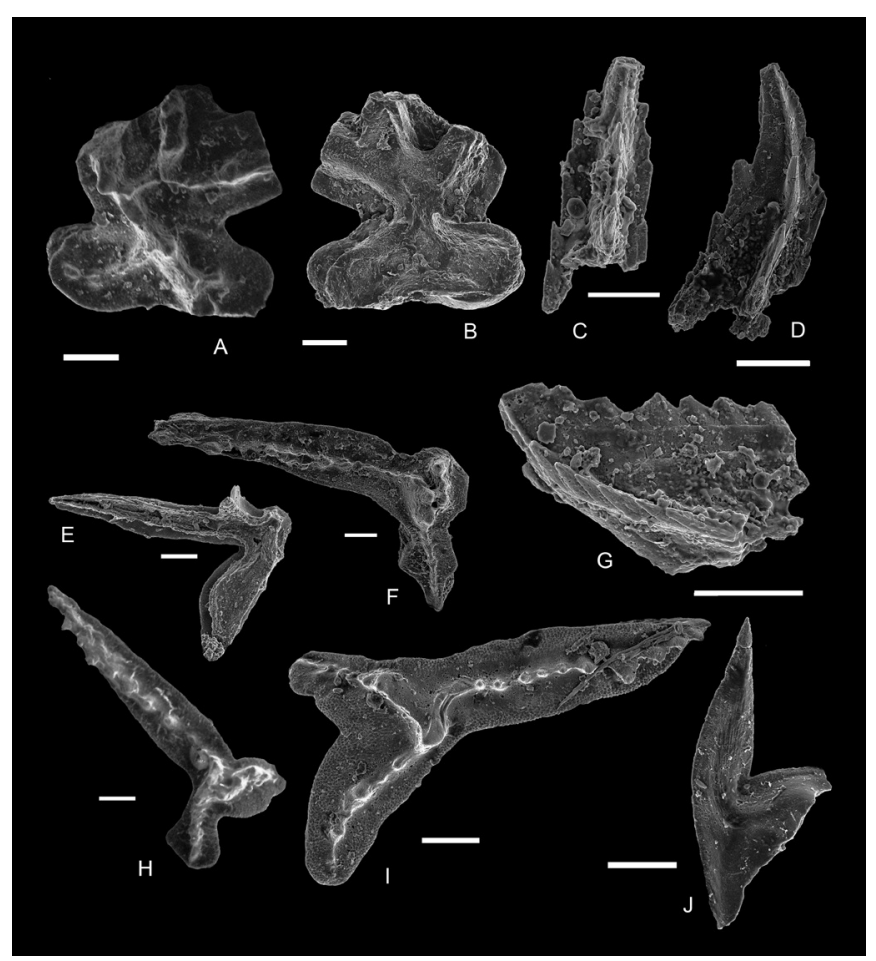

FIG. 3. Scanning electron microscope photomicrographs, scale bar 0,1 mm. 1-10. A-J: Eoplacognathus robustus Bergström. A. dextral Pa element, oral view, CORD MP 2228(1), PT 8. B. dextral Pa element, aboral view, CORD MP 2228(1), PT 8. C. Sa element, posterior view, CORD MP 2292(3), PT9. D. Sd element, lateral view, CORD MP 2292(4), PT9. E. dextral Pa element, aboral view, CORD MP 2225(2), PT 9. F. sinistral Pb element, oral view, CORD MP 2229 (4), PT 9. G. Sb element, lateral view, CORD MP 2292 (2) PT9. H. sinistral Pb, oral view, CORD MP 2229(1) PT9. I. dextral Pb element, oral view, CORD MP 2223(5), PT 9. J. M element, lateral view, CORD MP 2292(1), PT9.

Materials. Four hundred eighty five elements. Three hundred $\mathrm{Pa}$, one hundred seventy three $\mathrm{Pb}$, eight $\mathrm{S}$, and four M elements.

Description. We have nothing to add to the description by Bergström (1971) on the $\mathrm{Pa}$ and $\mathrm{Pb}$ elements.

M. The $\mathrm{M}$ element is represented by modified geniculate morphology. The cusp is erect and is longer than the anterior margin. The angle between anterior margin of the cusp and the anterior margin of the base is greater than $180^{\circ}$ and the anterior margin is thin and short. The angle between anterior and oral margins is less than $90^{\circ}$ and has a U-like shape.

Sa. The Sa element has an alate morphology. The element has three regularly denticulate processes. The denticles are fused in the base and climb through the cusp.

Sb. The tertiopedate element, clearly asymmetrical with a short cusp and erect to the tip. The three processes have regular and similar in shape procline denticles. These denticles appear high on the cusp.
Sd. The symmetrical quadriramate element with a short cusp. All the processes are regularly denticulate and connecting with the cusp through a carina.

$\mathrm{Sd}$ and Sa element present bad preservation, for this reason, we did not illustrate these both element.

\section{Remarks}

The Eoplacognathus apparatuses herein described are composed by six elements: $\mathrm{Pa}, \mathrm{Pb}, \mathrm{M}, \mathrm{Sa}, \mathrm{Sb}$, and $\mathrm{Sd}$. The $\mathrm{P}$ elements are abundant but the $\mathrm{S}$ and $\mathrm{M}$ elements are very poor in number. The recovering of $\mathrm{S}$ and $\mathrm{M}$ elements is possible when the collection of Eoplacognathus is large. The absence of the Sc element and decreasing number of the other $\mathrm{S}$ and the $\mathrm{M}$ elements could be explained following Löfgren and Zhang (2003) observation; these authors suggested a decrease of $\mathrm{S}$ elements in evolutionary trends between Lenodus-Yangzeplacognathus-Eoplacognathus 


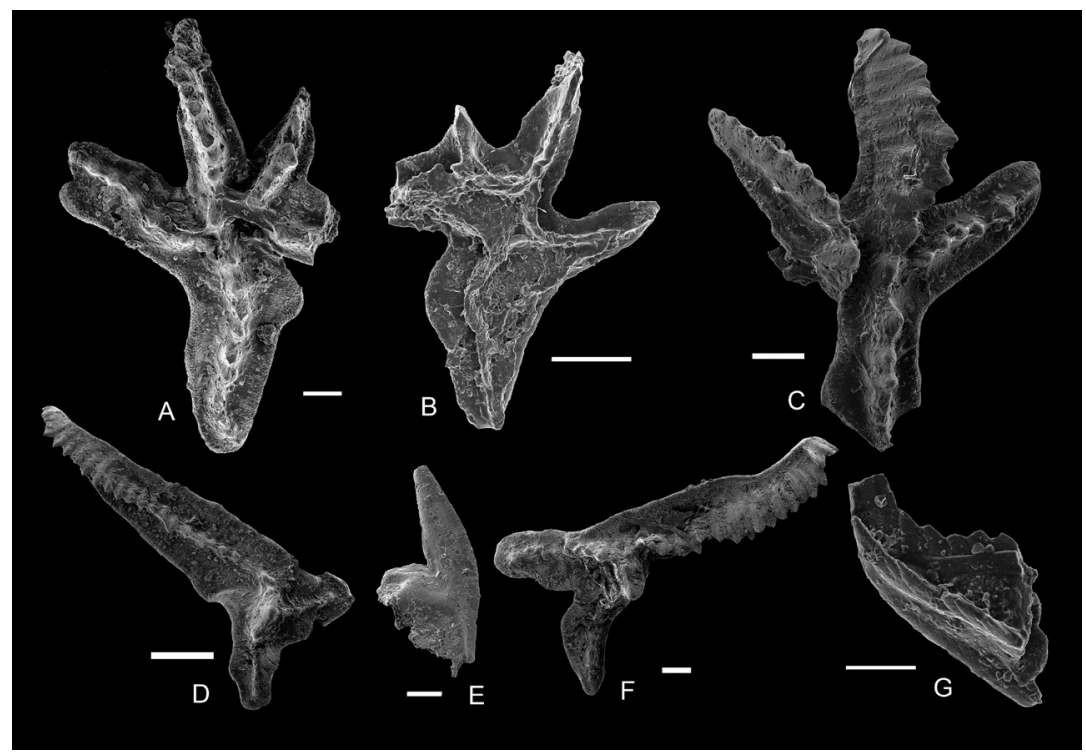

FIG. 4. Scanning electron microscope photomicrographs, scale bar 0,1 mm. A-G. Eoplacognathus lindstroemi (Hamar), all the elements from PT11'. A. mature dextral Pa element, oral view, CORD MP 2364 (1). B. juvenile dextral Pa element, aboral view, CORD MP 2364(2). C. mature sinistral Pa element, oral view, CORD MP 2364(3). D. sinistral Pb element, oral view, CORD MP 2362(2). E. M element, lateral view, CORD MP 2290(6). F. dextral Pb element, oral view, CORD MP 2361(2). G. Sc element, lateral view, CORD MP 2290(2).

apparatuses and the progressive disappearance of the bipennate element into these apparatuses.

The Eoplacognathus robustus and E. lindstroemi apparatuses from Ponón Trehué were compared to Eoplacognathus pseudoplanus and E. suecicus apparatuses from the Precordillera (Heredia, 2012; Mestre, 2012; Mestre and Heredia, 2013) (Table 1, Fig. 5). The analysis of these data inform that there is a great increasing of $\mathrm{P}$ elements over the $\mathrm{S}$ and $\mathrm{M}$ elements, and the early representatives of the genus neither provided Sc elements.

We have recognized that the $\mathrm{S}$ and $\mathrm{M}$ elements from $E$. robustus and $E$. lindstroemi can be identified as belonging to mature specimens. This datum allows inferring that the $\mathrm{S}$ and $\mathrm{M}$ elements representing juvenile and adult specimens are missing. Dzik (1976) proposed that the evolutionary process of the Eoplacognathus species let only platform elements in the apparatuses by the progressive demineralization of the $\mathrm{S}$ and $\mathrm{M}$ elements. Perhaps the $\mathrm{S}$ and $\mathrm{M}$ mature elements from our collection are mineralized as part of the ontogenetic process.

The $\mathrm{S}$ and $\mathrm{M}$ elements of the E. robustus and E. lindstroemi (early and late form) apparatuses were compared with those of Baltoniodus prevariabilis
TABLE 1. COMPARATIVE TABLE OF EOPLACOGNATHUS APPARATUS ELEMENTS. (*)

\begin{tabular}{lrrrr}
\hline & E. $\mathbf{p}$. & E. $\mathbf{s .}$ & E. . & E. $\mathbf{l}$. \\
\hline P & 47 & 33 & 45 & 473 \\
$\mathbf{S}$ & 18 & 5 & 6 & 8 \\
$\mathbf{M}$ & 7 & 1 & 3 & 4 \\
Total & 72 & 39 & 54 & 485 \\
& & & & \\
$\mathbf{P}$ & 65,3 & 84,6 & 83,3 & 97,5 \\
S & 25,0 & 12,8 & 11,1 & 1,6 \\
M & 9,7 & 2,6 & 5,6 & 0,8 \\
Total & 100,0 & 100,0 & 100,0 & 100,0 \\
\hline
\end{tabular}

(*) Elements recovered from E. p. (Eoplacognathus pseudoplanus). E. s. (Eoplacognathus suecicus); E. r. (Eoplacognathus robustus) and E. I. (Eoplacognathus lindstroemi) from the Precordillera and Ponón Trehué, respectively; amount and percentage of elements from each species displayed on figure 5 .

and B. variabilis (Fig. 6). The main differences in the $\mathrm{S}$ elements of these two genera are the orientation, shape, distribution and height of the denticles and the absence/presence of micro-striation on the cusps. 


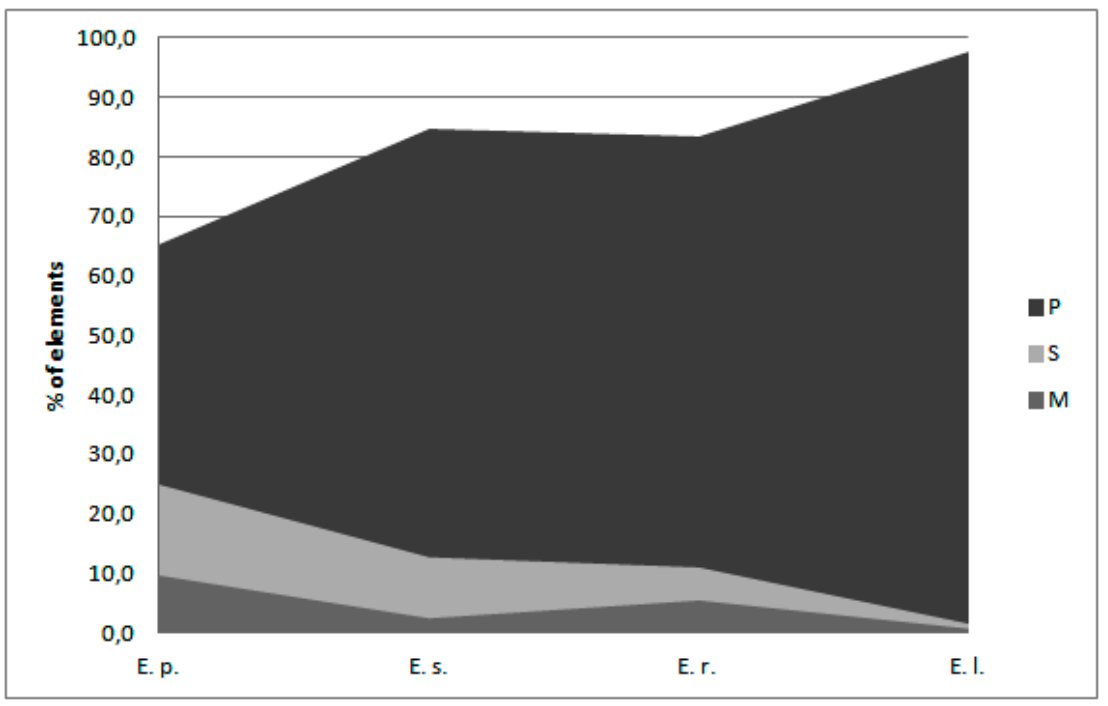

FIG. 5. Percentage of elements on the apparatuses of E. p. (Eoplacognathus pseudoplanus). E. s. (Eoplacognathus suecicus), E. r. (Eoplacognathus robustus) and E. I. (Eoplacognathus lindstroemi) from the Precordillera and Ponón Trehué.

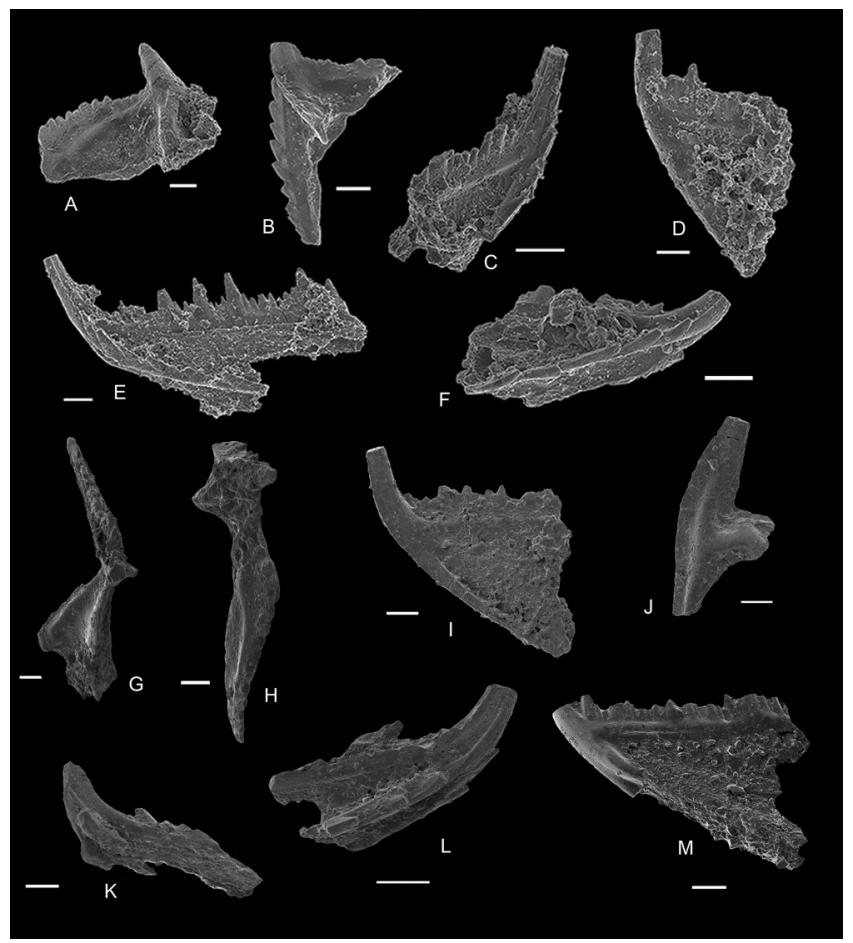

FIG. 6. Scanning electron microscope photomicrographs, scale bar 0,1 mm. A-F. Baltoniodus variabilis (Bergström), all elements from PT11'. A. Pa element, outer view, CORD MP-2259(1). B. Pb element, inner view, CORD MP-2259(2). C, E. Sa element, posterior view, CORD MP-2259(3). Lateral view, CORD MP-2259(4). D. Sc element, lateral view, CORD MP-2259(5). F. Sd element, lateral view, CORD MP-2259(6); G-M. Baltoniodus prevariabilis (Fåhræus), all elements from PT 9, G. Pa element, oral view, CORD MP-2257(1). H, K. Pb element. H. oral view, CORD MP-2257(2). K. lateral view, CORD MP-2257(3). I. Sc element, lateral view, CORD MP-2257(4). J. M element, lateral view, CORD MP-2257(5). L. Sd element, lateral view, CORD MP-2257(6). M. Sb element, lateral view, CORD MP-2257(7). 
For instance, the denticles are procline and uniform in height in the S elements of Eoplacognathus; on the other hand, Baltoniodus shows denticles erect that irregularly alternate in height on the posterior process. The cusp orientation of S elements in Eoplacognathus is procline, while in Baltoniodus is erect. The $\mathrm{Sb}$ elements (tertiopedate) of Eoplacognathus and Baltoniodus are very different, the first shows the three processes denticulate and the second has denticles only in the posterior process (Figs. 3, 4, 6). All these differences allow a correct identification of the S elements of Eoplacognathus.

The M elements of the Eoplacognathus present the obtuse angle between anterior margin of the cusp and the anterior margin of the base, similar that the $\mathrm{M}$ elements of genus Lenodus, in contrast the M element of Baltoniodus this angle is straight (Figs. 3, 4, 6).

\section{Conclusions}

The apparatuses of E. robustus and E. lindstroemi are described and illustrated for first time. The $\mathrm{S}$ and $\mathrm{M}$ elements added to these apparatuses allow proposing that the genus is composed by six elements. The Sc element (bipennate) was not retrieved. We note the main differences between the $\mathrm{S}$ and $\mathrm{M}$ elements from the coeval Eoplacognathus and Baltoniodus apparatuses for discriminating these both genera composition, allowing an accurate identification of the S elements of Eoplacognathus.

We propose considering the $\mathrm{P}$ element basal cavity as one of the main features of this group. This character could define among others the boundary between these two species, as already was suggested by Mestre and Heredia (2017). Further studies on the transitional form of E. robustus and E. lindstroemi would show if this feature can define a different species or genus between them.

Finally, we suggest the inclusion of the Eoplacognathus into the Balognathidae family. The new architecture of the Eoplacognathus apparatus is comparable to the genus Lenodus (sensu Löfgren and Zhang, 2003), where S and M elements keep the morphology and location through time, allowing a new insight on the evolution, paleobiology and phylogeny of this linage.

\section{Acknowledgements}

The authors wish to thank to CONICET for support the conodont research in Argentina, and M. González for her work at lab. Thanks to Dr. S. Bergström for several advices that improved the original manuscript. We also thank to Dra. F. Serra for suggestions and useful comments. This is a contribution to the International Geoscience Programme (IGCP) Project 653-The onset of the Great Ordovician Biodiversification Event.

\section{References}

Astini, R. 2002. Los conglomerados basales del Ordovícico de PonónTrehué (Mendoza) y su significado en la historia sedimentaria del terreno exótico de Precordillera. Revista de la Asociación Geológica Argentina 57 (1): 19-34.

Bassler, R.S. 1925. Classification and stratigraphic of McLish and Tulip Creek Formation (Middle Ordovician) of south-central Oklahoma. Oklahoma Geological Survey Bulletin 141: 1-53.

Beresi, M.; Heredia, S. 2000. Sponge spicule assemblages from the Middle Ordovician of PonónTrehué, Southern Mendoza, Argentina. Revista Española de Paleontología 15 (1): 37-48.

Bergström, S.M. 1971. Conodont Biostratigraphy of the Middle and Upper Ordovician of Europe and eastern North America. In Symposium on Conodont biostratigraphy (Sweet, W.C.; Bergström, S.M.; editors), Geological Society of America Memory 127: 83-157.

Bergström, S. 1983. Biogeography, evolutionary relationships and biostratigraphic significance of Ordovician platform conodonts. Fossils and Strata 15: 35-58.

Bergström, S.M.; Orchard, M.J. 1985. Conodonts of the Cambrian and Ordovician Systems from the British Isles. In A Stratigraphical lndex of Conodonts (Higgins, A.C.; Austin, R.L.; editors). Ellis Horwood Limited: 32-67. Chichester.

Bordonaro, O.; Keller, M.; Lehnert, O. 1996. El Ordovícico de PonónTrehué en la Provincia de Mendoza (Argentina): Redefiniciones estratigráficas. In Congreso Geológico Argentino, No. 13 y Congreso de Exploración de Hidrocarburos, No. 3, Actas I: 541-550. Buenos Aires.

Cingolani, C.; Varela, R. 1999. The San Rafael Block, Mendoza (Argentina): Rb-Sr Isotopic age of basement rocks. In South American Symposium on Isotope Geology, No. 2, Servicio Geológico Minero Argentino (SEGEMAR) Anales 24: 23-26. Córdoba.

Cingolani, C.; Heredia, S. 2001. Bloque de San Rafael: Cerro Bola y Ponón Trehué. Field Trip guide. In International Symposium on the Ordovician System, San Juan, 2003, Argentina. Instituto Superior de Correlación Geológica (INSUGEO), Serie Miscelánea 7: 7-20. 
Dzik, J. 1976. Remarks on the evolution of Ordovician conodonts. Acta Palaeontologica Polonica 21: 395-455.

Dzik, J. 1994. Conodonts of the Mójcza Limestone. In Ordovician carbonate platform ecosystem of the Holy Cross Mountain (Dzik, J.; Olempska, E.; Pisera, A.; editors). Palaeontologica Polonica 53: 43-128.

Hamar, G. 1964. The Middle Ordovician of the Oslo Region, Norway. 17. Conodonts from the lower Middle Ordovician of Ringerike. Norsk Geologisk Tidsskrift 44: 243-292.

Hamar, G. 1966. The Middle Ordovician of the Oslo region, Norway. 22. Preliminary report on conodonts from the Oslo-Asker and Ringerike districts. Norsk Geologisk Tidsskrift 46 (1): 27-83.

Hass, S.H. 1959. Conodonts from the Chappel Limestones of Texas. United States Geological Survey Professional Paper 294J: 364-400.

Heredia, S. 1982. Pygodus anserinus Lamont et Lindström (Conodonto) en el Llandeillano de la Formación PonónTrehué. Ameghiniana 19 (3-4): 101-104.

Heredia, S. 1996. El Ordovícico del Arroyo Ponón Trehué, sur de la provincia de Mendoza. In Congreso Geológico Argentino, No. 13 y Congreso de Exploración de Hidrocarburos, No. 3, Actas I: 601-605.

Heredia, S. 1998. Eoplacognathus robustus (Conodonta) en la Formación Ponón Trehué (Ordovícico Inferior), Sierra Pintada, provincia de Mendoza, Argentina. Ameghiniana 35 (3): 337-344.

Heredia, S. 2001. Late Llanvirn conodonts from Ponón Treuhué Formation, Mendoza, Argentina. Gaia 16: 101-117.

Heredia, S. 2002. Upper Llanvirn-Lower Caradoc Conodont Biostratigraphy, Southern Mendoza, Argentina. In Aspects of the Ordovician System in Argentina (Aceñolaza, F.G.; editor), Serie Correlación Geológica 16: 167-176.

Heredia, S. 2012. Bioestratigrafía de conodontes del Darriwiliano medio (Ordovícico) de Argentina: la Formación Las Aguaditas, Precordillera Central. Revista Mexicana de Ciencias Geológicas 29 (1): 76-86.

Heredia, S.; Mestre, A. 2015. The Balognathiid apparatuses of Eoplacognathus robustus Bergström and E. lindstroemi (Hamar). Stratigraphy 12 (2): 30-32.

Heredia, S.; Mestre, A. 2017. Remnant of the Ordovician carbonate platform (Ponón Trehué Formation), Mendoza, Argentina. In The Pre-Carboniferous Geological Evolution of the San Rafael Block, Western Argentina: Paleogeographic implications in the Proto-Andean Gondwana Margin (Cingolani, C.; editor), Springer Briefs in Earth System Sciences: 75-86.

Heredia, S.; Mestre, A.; Soria, T. 2014. Taxonomical review of the conodont genus Eoplacognathus Bergström and its stratigraphical record in the Ordovician of Argentina. In International Palaeontological Congress, No. 4. Ordovician biotas of Gondwana: responses to global climatic and eustatic events, and their biogeographic relationships within the Ordovician world (Harper, D.; Dronov, A.; editors), Actas 20: p. 850. Mendoza.

Hints, O.; Viira, V.; Nõlvak, J. 2012. Darriwilian (Middle Ordovician) conodont biostratigraphy in NW Estonia. Estonian Journal of Earth Sciences 61 (4): 210-226.

Lehnert, O.; Bergström, S.; Keller, M. ; Bordonaro, O. 1999. Middle Ordovician (Darriwillian-Caradocian) conodonts from the San Rafael region, west-central Argentina: Biostratigraphic, paleoecologic and paleogeographic implications. Bolletino Della Societá Paleontologica Italiana 37 (2-3): 199-214.

Löfgren, A .; Zhang, J.H. 2003. Element association and morphology in some Middle Ordovician platformequipped conodonts. Journal of Paleontolog 77: 723-739.

Melgren, J.; Schmitz, B.; Ainsaar, L.; Kirsimäe, K.; Eriksson, M. 2012. Conodont dating of the Middle Ordovician breccia cap-rock limestone on Osmusaar Island, northwestern Estonia. Estonian Journal of Earth Sciences 61 (3): 133-148.

Mestre, A. 2012. Bioestratigrafía de Conodontes del Techo de la Formación San Juan y del Miembro Inferior de la Formación Los Azules, Cerro La Chilca, Precordillera de San Juan. Ameghiniana 49: 185-197.

Mestre, A.; Heredia, S. 2013. La Zona de Yangtzeplacognathus Crassus (Conodonta), Darriwiliano de la Precordillera Central de San Juan, Argentina. Ameghiniana 50 (4): 407-417.

Mestre, A.; Heredia, S. 2017. New taxonomical insights on the conodont genus Lenodus (Lower Darriwilian) from the Precordillera, San Juan, Argentina. In Progress on Conodonts Investigation (Liao, J.C.; Valenzuela-Ríos, J.I.; editors). In Fourth International Conodont Symposium. (ICOS IV). Instituto Geológico y Minero de España, Cuadernos del Museo Geominero 22: 49-54. Madrid.

Purnell, M.A.; Donoghue, P.C.J.; Aldridge, R.J. 2000. Orientation and anatomical notation in conodonts. Journal of Paleontology 74: 113-122.

Ramos, V.; Vujovich, G.I.; Dallmeyer, R.D. 1996. Los klippes y ventanas tectónicas preándicas de la Sierra de Pie de Palo (San Juan): edad e implicaciones tectónicas. In Congreso Geológico Argentino, No. 13 y Congreso de Exploración de Hidrocarburos, No. 3, Actas 5: 377-391.

Stauffer, C. 1935. The conodont fauna of the Decorah shale (Ordovician). Journal of Paleontology 9: 596-620. 
Stouge, S.; Bagnoli, G. 1990. Lower Ordovician(VolkhovianKunda) conodonts from Hagudden, northern Öland, Sweden. Palaeontographia Italica 77: 1-54.

Stouge, S.; Bagnoli, G. 1999. The suprageneric classification of some Ordovician prioniodontid conodonts. Bolletino della Società Paleontológica Italiana 37: 145-158.

Stouge, S.; Bauert, G.; Bauert, H.; Nolvak, J.; Rasmussen J.A. 2016. Upper Middle to lower Upper Ordovician chitinozoans and conodonts from the Bliudziai-150 core, southern Lithuania. Canadian Journal of Earth Sciences 53: 781-787.

Sweet, W.C. 1981. Macromorphology of elements and apparatuses. In Treatise on Invertebrate Paleontology, Pt. W. Miscellanea, Supplement 2, Conodonta (Robison, R.A.; editor). Geological Society of America and University of Kansas Press: 5-20. Lawrence.

Sweet, W.C. 1988. The Conodonta. Morphology, Taxonomy, Paleoecology, and evolutionary history of a long-extinct animal phylum. Oxford Monographs on Geology and Geophysics, Clarendon Press 10: 224 p. New York. Viira, V. 2011. Lower And Middle Ordovician Conodonts From The Subsurface Of SE Estonia and adjacent Russia. Estonian Journal of Earth Sciences 60: 1-21. Wu, R-C.; Stouge, S.; Zhan, R-B.; Liu, J-B.; Liang Y. 2016. Conodont faunal dynamics across the Middle and Upper Ordovician boundary in the Yichang area, western Hubei Province, South China. Canadian Journal of Earth Sciences 57: 1-9.

Zhang, J.H. 1998. Middle Ordovician Conodonts from The Atlantic Faunal Region and the evolution of key conodont genera. Meddelanden från Stockholms Universitets Institution för Geologi Och Geokemi 298: 5-27.

Ziegler, W. 1973. Catalogue Of Conodonts I. Schweizerbart'sche Verlagsbuchhandlung, Stuttgart: $504 \mathrm{p}$.

Manuscript received: February 20, 2018; revised/accepted: November 21, 2018; available online: February 04, 2019. 